\title{
JOINT ELECTRICITY AND HEAT PRODUCTION POSSIBILITIES ON THE BASIS OF THE DISTRICT TRIGENERATION PLANT
}

\author{
Vadim Ershov ${ }^{1, *}$, and Ekaterina Tarasova ${ }^{1}$ \\ ${ }^{1}$ National Research Tomsk Polytechnic University, 634050 Tomsk, Russia
}

\begin{abstract}
Renewable energy has become increasingly important in the last decade due to the limited reserves of fossil fuels and environmental issues related to $\mathrm{CO} 2$ emissions. The paper investigates the joint production possibility of electricity and heat in the Tomsk district Stepanovka, using modern trigeneration plant. The analysis was performed based on a comparison of the two alternatives for the area: the use of a diesel power plant (DPP) or gas-piston units (GPU) on biofuel. Technical and economic indicators for two different systems were calculated to evaluate the projects effectiveness.
\end{abstract}

\section{Introduction}

Reduction of natural hydrocarbon resources, rise in price of oil and gas production systems, electric and heat energy tariffs increase, environment pollution by emission of carbon dioxide and global warming [1,2] enhance the interest in the use of renewable energy sources. Personal power plants, operating on renewable energy, can become an alternative to traditional diesel power plants, operating on imported and expensive fuel, for rural areas of Tomsk region.

Energy resources consumption reduction and their efficient allocation can be provided by more efficient power plant with a combined production of heat / electricity / cold. [1]

The heat excess generated in the motor can be used for heat and cold generation for consumer needs. Usually, heat demand is dramatically reduced in summer, due to heating and ventilation necessity deficiency. However it's possible to dispose of the large volumes heat by means of cold power generation for manufacture process needs. This is possible by including compressor or absorption conditioners in the heat network diagram. This allows to increase the plant efficiency in summer time. $[1,2,3]$

The current state of the Stepanovka district communal infrastructure is characterized by a high grade of equipment deterioration; deterioration rate ranges from $48 \%$ to $82 \%$ for most objects. On the average, $68 \%$ of utilities have served set time-limit. This results in excessive networks losses, the low equipment efficiency factor, excessive accident risk. This requires a higher cost of operation and maintenance of municipal infrastructure. Special attention should be given to following utilities problems:

*Corresponding author: kachalov@tpu.ru 
- high level of fixed assets depreciation;

- engineering systems low reliability, especially electric power supply systems;

- insufficient replacement scale of electrical networks and modernization of boiler stations and DES equipment;

- insufficient network replacement scale and retrofitting.

According to the project the electrical energy production is planned to be covered by the diesel power plant and the biomass gas piston installation, the electric and heating systems will be reconstructed. Wastes from agriculture and timber industry may be used as a biofuel source. The exhaust steam will be provided for socially important facilities heating such as kindergarten, school, hospital and others to enhance efficiency.

The article deals with three major project aspects:

- required heat and electricity loads analysis and assessment;

- the technical and economic viability analysis;

- environmental impact assessment.

\section{The district energy consumption volume assessment}

It is necessary to evaluate the heat and electric power consumption volumes for power supply system optimization. The utilities consumption standard values for the hot water supply in premises are shown in the Table 1.

Table 1. Consumption standard values for the hot water supply.

\begin{tabular}{|c|c|c|}
\hline No. & The premises accomplishment rate & $\begin{array}{c}\text { The utilities consumption ratio } \\
\left(\mathrm{m}^{3} \text { per month for 1 person }\right)\end{array}$ \\
\hline 1 & $\begin{array}{c}\text { Dwellings with central water supply, sewage and } \\
\text { hot water supply }\end{array}$ & 2.16 \\
\hline 2 & $\begin{array}{c}\text { Dwellings with central water supply, hot water } \\
\text { supply and without centralized sewerage }\end{array}$ & 2.51 \\
\hline 3 & $\begin{array}{c}\text { Dwellings with central water supply, sewage and } \\
\text { hot water, equipped with sinks, kitchen sinks, } \\
\text { showers }\end{array}$ & 3.02 \\
\hline 4 & $\begin{array}{c}\text { Dwellings with central water supply, sewage and } \\
\text { hot water, equipped with seating baths, sinks and } \\
\text { shower }\end{array}$ & 3.11 \\
\hline 5 & $\begin{array}{c}\text { Dwellings with central water supply, sewage and } \\
\text { hot water, equipped with 1500-1700 mm baths, sink } \\
\text { and shower }\end{array}$ & \\
\hline
\end{tabular}

The utilities consumption ratio values for dwellings heating are shown in the Table 2.

Table 2. The utilities consumption ratio values for heating in residential and non-residential premises of the Tomsk region during the heating season.

\begin{tabular}{|c|c|c|}
\hline \multirow{2}{*}{$\begin{array}{c}\text { Number of floors in } \\
\text { a building }\end{array}$} & \multicolumn{2}{|c|}{ Gcal per 1 sq. meter of total floor area per month } \\
\cline { 2 - 3 } & Dwellings built before 1999 & Dwellings built after 1999 \\
\hline 1 & 0.0462 & 0.0194 \\
\hline 2 & 0.0457 & 0.0175 \\
\hline 3 & 0.0288 & 0.0177 \\
\hline 4 & 0.0288 & 0.0155 \\
\hline 5 & 0.0247 & 0.0155 \\
\hline
\end{tabular}




\section{The power plant configuration alternatives}

1) Diesel power plant

2) Biofuel gas-piston installation

The annual saving of equivalent fuel consumption, obtained due to the combined development of energy by a mini-CHPP in comparison with a separate power generation by $\mathrm{CPP}$ and thermal energy by a local boiler station:

$\Delta B=B_{e q}-B \mathrm{~kg}$ eq.t./year;

Where $B=b_{E}^{m C H P P} E_{Y E A R}^{m C H P P}$ - annual equivalent fuel consumption by mini-CHPP. $\mathrm{B}_{\mathrm{eq}}-$ annual equivalent fuel consumption generated separately by CPP and thermal energy in a local boiler station including transport energy losses;

$b_{E}^{m C H P P}=\frac{0.123}{\eta_{E}^{I C E}}-$ equivalent fuel unit consumption of mini-CHPP, gas-piston internal combustion engine (ICE);

$E_{Y E A R}^{m C H P P}=E_{C O N S}-$ annual power generation of mini-CHPP, $\mathrm{kW} * \mathrm{~h} /$ year.

The fuel economy of the combined energy development is distributed in proportion to (types of the developed energy) relative shares:

$\Delta B_{E}=\Delta B \beta_{E} \mathrm{~kg}$ eq.t./year;

$\Delta B_{H}=\Delta B \beta_{H} \mathrm{~kg}$ eq.t./year;

Average annual unit consumption values of mini-CHPP equivalent fuel:

- for generated electric energy:

$b_{E}^{m C H P P}=\frac{B_{E}^{H P P 1}-\Delta B_{E}}{E_{C O N S}\left(1+\alpha_{O N}\right)} \mathrm{kg}$ eq.t. $/ \mathrm{kW}^{*} \mathrm{~h} ;$

$\alpha_{O N}$ - power consumption coefficient for mini-CHPP own needs;

- for generated heat energy $Q_{H} \mathrm{~kW}^{*} \mathrm{~h}$ :

$b_{H}^{m C H P P}=\frac{B_{B O I L}-\Delta B_{H}}{Q_{H}} \mathrm{~kg}$ eq.t. $/ \mathrm{kW}^{*} \mathrm{~h} ;$

Calculated average annual unit consumption values of mini-CHPP equivalent fuel:

- for generated electric energy:

$B_{E}^{m C H P P}=\ni_{G E N}^{m C H P P} \cdot b_{E}^{m C H P P} \mathrm{~kg}$ eq.t./year;

- for generated heat energy:

$B_{H}^{m C H P P}=Q_{H} \cdot b_{H}^{m C H P P} \mathrm{~kg}$ eq.t./year;

The equivalent value of a total average annual consumption of conditional fuel used for mini-CHPP spent for production of electric and thermal energy: 
$B_{E Q}=B_{E}^{m C H P P}+B_{H}^{m C H P P} \mathrm{~kg}$ eq.t./year;

The corrected shares of the equivalent fuel consumption used by mini-CHPP for generation of electric and thermal energy:

$\gamma_{E}=\frac{B_{E}^{m C H P P}}{B_{E Q}}$

$\gamma_{H}=\frac{B_{H}^{m C H P P}}{B_{E Q}}$

Total annual expenses for mini-CHPP:

$E=E_{H \Sigma}+E_{B O I L}^{\prime}+E_{S}+E_{A L L}+E_{A M}$ thousand rub;

Where $E_{H \Sigma}=E_{H}^{R E A}+E_{H}^{E S T}$ - total annual expenditures for mini-CHPP biogas;

$E_{H}^{R E A}=B_{B G}^{\text {OVER }} C_{B G}$ - total annual expenses for mini-CHPP biogas;

$E_{H}^{E S T}=B_{B G}^{E S T} C_{B G}$ - total annual expenses for power supply;

$B_{B G}^{E S T}$ - total consumption of mini-CHPP biogas for power supply;

$C_{B G}$ - biogas costs, related to one ton of equivalent fuel;

$E_{B O I L}^{\prime}$ - expenses for additional heat power supply during winter, generated by boiler station;

$E_{S}=12 n E_{E}^{m C H P P} W-$ annual expenses for staff salary;

$n$ - mini-CHPP staff coefficient, person/MW;

$E_{E}^{n C H P P}-$ mini-CHPP electrical output capacity, MW;

$W$ - corporate employee monthly salary, rub/month;

$E_{A L L}=0.3 E_{S}$ - salary allocation, rub;

Annual depreciation:

$E_{A M}=p_{A M} C_{\Sigma}$

Where $p_{A M}$-amortization allocations standard

Total mini-CHPP installed costs:

$$
C_{\Sigma}=\left(C_{E Q}+C_{D E}+C_{S C}+C_{C S}+C_{J C}\right)
$$

Where $K_{O B}$ - mini-CHPP equipment costs, rub.;

$C_{D E}=(0.05-0.1) C_{S C}-$ design costs, rub.; 
$C_{S C}=(0.15-0.2) C_{E Q}$ - construction and installation costs, rub.;

$C_{C S}=(0.03-0.05) C_{E Q}-$ commissioning costs, rub;

$C_{J C}=k_{C O N N} E_{E}$ - power system connection costs, rub.;

$k_{C O N N}$ - unit connection costs, rub. $/ \mathrm{kW}$;

Production annual costs:

- electrical energy

$E_{E}=\gamma_{E} E_{\Sigma}$ rub./year;

-heat energy

$E_{H}=\gamma_{H} E_{\Sigma}$ rub./year.

Mini-CHPP electrical and heat energy prime costs (что это за термин?-себестоимость):

- electrical energy prime costs:

$S_{E}=\frac{E_{E}}{E_{\text {CONS }}} \mathrm{rub} . / \mathrm{kW} \cdot \mathrm{h}$

- heat energy prime costs:

$S_{H}=\frac{E_{H}}{Q_{H}^{m C H P P}} \mathrm{rub} . / \mathrm{kW} \cdot \mathrm{h} ;$ or $\quad S_{H}=\frac{E_{H}}{1163 Q_{H}^{m C H P P}} \mathrm{rub} . / \mathrm{Gcal}$;

Annual money inflow by means of energy saving using gas-piston mini-CHPP power supply system:

$\Delta C_{Y E A R}=C_{E L}+E_{H}+P_{E} ;$

Annual electric energy costs if electric network is used for power supply:

$C_{E L}=E_{C O N S} T_{E}$ rub./year;

Where $T_{E}$ - tariff on electric energy, consumed from central electric network, rub./kW*h;

Heat power supply costs using local boiling station:

$C_{H}=Q_{H} T_{H}$ rub./year;

Where $T_{H}$ - local boiling station heat energy tariff, rub./kW $\cdot \mathrm{h}$.

Excess electric power selling, generated by mini-CHPP and provided to electric networks:

$\Delta E_{\text {YEAR }}=E^{m C H P P}-E_{C O N S} \mathrm{~kW} \cdot \mathrm{h} /$ year;

Excess electric power selling annual profit:

$P_{E}=\Delta E_{Y E A R} T_{E}$ rub./year; 
Annual profit from construction, taking into account expenses of mini-CHPP and excess electric power sale, rub/year:

$P_{t}=\Delta C_{Y E A R}-\Delta H_{T C}-\Delta H_{P I}+A-E$

$\Delta H_{T C}=0.02 C_{\Sigma}$ - property tax change due to investment, rub/year;

$\Delta H_{P I}=0.2 \Delta C_{Y E A R}-$ tax payments increment, rub/year;

$A=p_{A M} C_{\Sigma}$ rub/year - depreciation charges;

$p_{A M}-$ depreciation charges coefficient;

Mini-CHPP construction net income:

$N I=\sum_{0}^{n} \Delta C_{Y E A R}-C_{\Sigma}$

Where $\sum_{0}^{n} \Delta C_{Y E A R}$ - Money inflow during $n$ mini-CHPP maintenance years, rub.

Net present value:

$N P V=\sum_{t=0}^{n} \frac{P t}{(1+g)^{t}}-\sum_{t=0}^{m} \frac{K t}{(1+g)^{t}} ;$

Gas-piston biogas mini-CHPP construction payback period:

$T_{\text {oк }}=\frac{C_{\Sigma}}{P_{t}}$

\section{Environment emissions reduction}

Annual gross atmosphere emissions were calculated for the operating diesel installations according to the technique [2]. As basic data we used:

- data from technical manufacturer documentation of diesel installation operational power for calculation of the maximum onetime emissions;

- calculations result of standard values of diesel engine annual fuel consumption for the evaluation of gross emissions in the atmosphere.

The average specific values of emissions indicators which were given in the technique [2] reflect the main toxicity parameters change regularities of diesels depending on a load and high-speed operating mode of the power plant, and also power and tip speed ratio of the diesel engine [2], [3]. Also, working process organization features of multi-cylinder powerful diesel installations are taken into account.

Emissions calculations are performed for the following harmful substances coming to the atmosphere with the exhaust gases of the diesel installations:

- carbon oxide $(\mathrm{CO})$;

- nitrogen oxides (NOx) (in terms of $\mathrm{NO} 2$ );

- hydrocarbons $(\mathrm{CH})$ ). 
For stricter emissions accounting of gas-diesel installations it is expedient to be guided by ecological indicators certificates [2.3].

\section{Conclusion}

Energy resources consumption reduction and their efficient allocation can be provided by more efficient power plant with a combined production of heat / electricity.

Calculation results have shown that during the internal combustion engines work on pyrolysis gas there is a significant decrease in gross emissions in comparison with diesel installations. Calculated decrease has accounted for:
$\checkmark \quad \mathrm{CO}$ by $42 \%$;
$\checkmark \quad$ NOx by $50 \%$;
$\checkmark \quad$ CH by $93 \%$;
$\checkmark \quad$ C (soot) by $99,5 \%$;
$\checkmark \quad \mathrm{SO}_{2}$ by $99,6 \%$;
$\checkmark \quad \mathrm{CH}_{2} \mathrm{O}$ by $98 \%$.

\section{References}

1. European Technology Platform on Renewable Heating and Cooling: 2020 - 2030 2050, Common Vision for the Renewable Heating \& Cooling sector in Europe, Luxembourg: Publications Office of the European Union (2011)

2. H. Zinko et al., International Energy Agency (2008)

3. A. Nosrat, J. M. Pearce, Appl. Energy 88, 9 (2011) 